Jurnal Health Sains: p-ISSN: 2723-4339 e-ISSN: 2548-1398

Vol. 3, No. 1, Januari 2022

\title{
UJI AKTIVITAS ANTI BAKTERI DARI FRAKSI DAUN AREUY KIKUNTI (POTHOS JUNGHUHNII DE VREISE) TERHADAP BAKTERI STAPHYLOCOCCUS AUREUS DAN ESCHERICHIA COLI
}

\author{
Purwati, Wahyuli \\ Universitas 17 Agustus 1945, Jakarta Utara, Indonesia \\ Email: purwati@uta45jakarta.ac.id, wahyuliyuli37@gmail.com
}

\begin{tabular}{|c|c|}
\hline INFO ARTIKEL & ABSTRAK \\
\hline $\begin{array}{l}\text { Diterima } \\
5 \text { Januari } 2022 \\
\text { Direvisi } \\
15 \text { Januari } 2022 \\
\text { Disetujui } \\
\text { 25 Januari } 2022\end{array}$ & $\begin{array}{l}\text { Tanaman obat tradisional merupakan tanaman yang sangat populer } \\
\text { untuk dimanfaatkan sebagai bahan baku obat tradisional salah satunya } \\
\text { adalah Daun Areuy kikunti (Photos junghuhnii de vreise). Penelitian ini } \\
\text { bertujuan untuk melihat fraksi n-heksan, etil asetat, dan butanol dari } \\
\text { daun Areuy kikunti (Photos jughuhnii de vreise) yang dapat } \\
\text { menghambat pertumbuhan bakteri terhadap Staphylococcus aureus dan }\end{array}$ \\
\hline $\begin{array}{l}\text { Kata Kunci: } \\
\text { fraksi daun areuy } \\
\text { kikunti (photos } \\
\text { junghuhnii de } \\
\text { vreise); antibakteri; } \\
\text { staphylococcus } \\
\text { aureus; escherichia } \\
\text { coli }\end{array}$ & $\begin{array}{l}\text { Escherichia Coli dengan menggunakan metode difusi kertas cakram. } \\
\text { Pelarut yang digunakan untuk fraksi Daun Areuy kikunti yaitu pelarut } \mathrm{n} \text { - } \\
\text { heksan, etil asetat dan butanol. Larutan uji yang digunakan dalam } \\
\text { pengujian antibakteri adalah larutan hasil fraksinasi dengan variasi } \\
\text { konsentrasi }(31,25 \mu \mathrm{g} / \mathrm{mL}, 62,5 \mu \mathrm{g} / \mathrm{mL}, 125 \mathrm{ug} / \mathrm{ml}, 250 \mu \mathrm{g} / \mathrm{mL} \text { dan } 500 \\
\mu \mathrm{g} / \mathrm{mL}) \text { dan sebagai kontrol positif digunakan disk antibiotik yaitu } \\
\mathrm{kloramphenikol} 30 \mu \mathrm{g} / \mathrm{mL} \text { dan sebagai kontrol negatif yaitu DMSO. } \\
\text { Hasil penelitian menujukkan bahwa fraksi daun Areuy kikunti memiliki } \\
\text { kemampuan sebagai antibakteri terhadap bakteri Staphylococcus aureus } \\
\text { dan Escherichia coli. pada fraksi Etil asetat dengan diameter } 10,5 \text { mm } \\
\text { dan bakteri Escherichia coli pada diameter } 8,5 \mathrm{~mm} \text { pada konsentrasi } \\
\text { 500ug/ml yaitu dalam kategori lemah. }\end{array}$ \\
\hline
\end{tabular}

Keywords:

fraction of pothos

leaves (pothos

junghuhnii de

vriese), anti-

bacteria,

staphylococcus

aureus, escherichia

\section{ABSTRACT}

Traditional medicinal plants are popular plants to be used as the raw material of traditional medicine, for example, Pothos leaves (Pothos junghuhnii de vriese). This study aimed at observing the $N$-Hexane fraction, ethyl acetate, and butanol from Pothos leaves (Pothos junghuhnii de vriese) that can inhibit the bacteria growth in Staphylococcus aureus and Escherichia coli by using the disk diffusion method. The solvents used for the fraction of Pothos leaves were $N$ hexane, ethyl acetate, and butanol. The test solvent used in antibacterial testing was the solvent for fractionation at various concentrations, namely $31.25 \mu \mathrm{g} / \mathrm{mL}, 62.5 \mu \mathrm{g} / \mathrm{mL}, 125 \mu \mathrm{g} / \mathrm{mL}, 250 \mu \mathrm{g} / \mathrm{mL}$, and 500 $\mu \mathrm{g} / \mathrm{mL})$. Moreover, an antibiotic disk, namely chloramphenicol, was a positive control, while DMSO was the negative control. The result showed that the fraction of Pothos leaves had antibacterial activity against Staphylococcus aureus and Escherichia coli. The fraction of ethyl acetate with a diameter of $10.5 \mathrm{~mm}$ and Escherichia coli with a diameter of $8.5 \mathrm{~mm}$ at a concentration of $500 \mathrm{ug} / \mathrm{ml}$ were in the 'poor' category

$\begin{array}{ll}\text { How to cite: } & \text { Purwati \& Wahyuli (2022) Uji Aktivitas Anti Bakteri dari Fraksi Daun Areuy Kikunti (Pothos } \\ & \text { Junghuhnii De Vreise) terhadap Bakteri Staphylococcus Aureus dan Escherichia Coli. Jurnal Health } \\ & \text { Sains 3(1). https://doi.org/10.46799/jhs.v3i1.403 } \\ & 2723-6927 \\ \text { E-ISSN: } & \text { Ridwan Institute } \\ \text { Published by: } & \end{array}$




\section{Pendahuluan}

dua lapisan yaitu fraksi n-heksan dan methanol air perbandingan 1:1. Lapisan $\mathrm{N}$ Heksan (bagian atas) dikeluarkan dari corong pisah lalu ditampung. (Restiana, 2019).

Fraksi metanol: air difraksinasi kembali dengan etil asetat dilanjutkan dengan butanol, masing-masing difraksinasi perbandingan Tanaman obat tradisional merupakan tanaman yang sangat popular untuk dimanfaatkan sebagai bahan baku obat tradisional (Kumoro, 2015). Di Indonesia terdapat berbagai jenis tumbuhan obat yang digunakan sebagai bahan baku industri obat tradisional, industri jamu, bumbu, serta untuk kebutuhan ekspor. (Pertanian, 2012).

Pothos scandens L. (Araceae) adalah obat aroid yang umumnya dikenal sebagai 'Batilata' di antara masyarakat suku di daerah perbukitan Bangladesh. Seluruh tanaman digunakan untuk mengobati gangguan kulit, asma, gigitan ular, diare, kanker, cacar, keseleo, epilepsi, kejang, dan luka. Kebutuhan ekspor. (Bhandary et al., 1995).

Penggunaan antibakteri merupakan solusi untuk menangani berbagai penyakit infeksi (Wardhani \& Sulistyani, 2012). Antibakteri merupakan senyawa yang mampu menghambat pertumbuhan bakteri. Penggunaan bakteri tidak terkontrol dapat mendorong terjadinya perkembangan resistensi terhadap bakteri yang diberikan. Adanya resistensi ini menimbulkan banyak masalah pengobatan penyakit infeksi, sehingga diperlukan usaha untuk mengembangkan obat tradisional berbahan herbal yang dapat membunuh bakteri untuk menghindari terjadinya resistensi (Handoko, 2013).

Penyakit infeksi merupakan salah satu permasalahan kesehatan yang disebabkan oleh mikroorganisme seperti virus, parasit, jamur dan bakteri. Bakteri patogen yang sering meyebabkan infeksi pada manusia dalam komunitas maupun secara nosocomial adalah bakteri staphylococcus aureus (Fitri \&
Yasmin, 2011). Dan bakteri Escherichia coli merupakan bakteri yang menyebabkan penyakit bila resistensi usus melemah, bakteri akan menyerang jaringan dinding usus yang menyebabkan diare pada usus manusia (Dewi et al., 2014).

\section{Metode Penelitian}

Alat yang digunakan dalam peneltian ini adalah Alat-alat yang digunakan dalam penelitian ini adalah Timbangan Analitik, Hotplate, Inkubator, Laminair Air Flow (LAF), Autoclave, Sendok tanduk, Batang pengaduk, Magnetic stirrer, Kertas perkamen, Spatel, Koran, Karet, Cawan petri, Kertas saring, Kapas, Pinset, Batang L, Mikropipet, Plastik wrap, Allumunium foil, Erlenmeyer, Beaker glass, Rak, Gelas Ukur, Pipet Tetes, Botol Semprot, Jangka Sorong, Jarum Ose, Pembakar Bunsen.

Bahan-bahan yang digunakan dalam penelitian ini adalah Daun Areuy Kikunti, aquadest, etil asetat, n-heksan, butanol, Muller Hinton Agar (MHA), Bakteri Staphylococcus aureus ATCC 25923, Bakteri Eschericia Coli ATCC 25922.

Ekstrak metanol daun Areuy Kikunti dilarutkan dengan perbandingan3:1 setelah tercampur, fraksi metanol : air difraksinasi dengan N-Heksan Selanjutnya campuran dimasukkan ke dalam corong pisah kapasitas $250 \mathrm{~mL}$ di kocok selama 2-3 menit dan dibiarkan hingga terbentuk 1:1. Fraksi etil asetat dan butanol masing-masing ditampung. fraksi N-Heksan, fraksi etil asetat dan Fraksi butanol yang telah ditampung dipekatkan dengan rotary evaporator sehingga didapat ekstrak fraksi N-Heksan, etil asetat dan butanol fraksi yang diperoleh kemudian di uapkan di atas waterbath pada suhu $50^{\circ} \mathrm{C}$ sampai diperoleh fraksi kental. (Restiana, 2019).

Pengujian aktivitas antibakteri terhadap bakteri Staphylococcus aureus dan Escherichia coli. Pengujian aktivitas antibakteri menggunakan difusi agar dengan 
menggunakan kertas cakram berdiameter 6 mm (Nagappan et al., 2011) dengan konsentrasi $31,25 \mu \mathrm{g} / \mathrm{mL}, 62,5 \mu \mathrm{g} / \mathrm{mL}, 125$ $\mu \mathrm{g} / \mathrm{mL}, \quad 250 \mu \mathrm{g} / \mathrm{mL}, \quad 500 \mu \mathrm{g} / \mathrm{mL}$ untuk masing-masing uji bakteri. Pengujian dilakukan menggunakan metode difusi cakram pada MHA steril. Medium MHA agar cair steril disiapkan dan didinginkan sampai memadat. Bakteri uji disebarkan diatas media MHA dengan menggunakan mikropipet 20 mL. Lakukan usapan menggunakan batang $\mathrm{L}$ sampai merata pada seluruh permukaan cawan petri yang berisi media agar (Handoko, 2013). Perlakuan ini dilakukan disekitar api Bunsen. Setelah itu kertas cakram diletakkan diatas media, kemudian kertas cakram ditetesi dengan 5 variasi konsentrasi. Kontrol negatif DMSO dan Kontrol positif digunakan cakram Chloramphenicol $30 \mu \mathrm{g} / \mathrm{mL}$ (masing-masing sebanyak $10 \mathrm{ml}$ ) cawan petri kemudian diinkubasi pada suhu $37^{\circ} \mathrm{C}$ selama 1 x 24 jam (Raihana et al., 2011).

Pengamatan dan Pengukuran Zona Hambat pengamatan dilakukan setelah 1 x 24 jam masa inkubasi. Daerah pada sekitaran cakram menunjukkan kepekaan hasil fraksinasi terhadap bakteri bakteri yang digunakan sebagai bahan uji yang dinyatakan dengan diameter zona bening. Diameter zona bening diukur menggukan jangka sorong dengan satuan milimeter ( $\mathrm{mm})$.

\section{Hasil dan Pembahasan}

a. Fraksinasi Daun Areuy Kikunti fraksinasi daun areuy kikunti dilakukan secara bertahap-tahap dengan tujuan supaya hasil yang didapatkan maksimal, fraksinasi sendiri adalah proses penarikan senyawa pada suatu ekstrak dengan menggunakan dua macam pelarut yang saling tidak bercampur, tujuannya untuk mengambil senyawa aktif dengan kepolaran nya. Fraksinasi n-heksan berupa lapisan berwarna hijau, dipekatkan kembali menggunakan rotary vacum evaporator di peroleh ekstrak kental n- heksan sebanyak 52,39 dengan rendemen sebesar $1,50 \%$, lapisan air yang telah dipisahkan dengan n-heskan kemudian di fraksinasi kembali menggunakan etil asetat sebanyak $500 \mathrm{~mL}$, fraksinansi etil asetat berupa lapisan berwarna hijau diperoleh ekstrak kental sebanyak 36,3 dengan rendemen sebesar 1,04\%. lapisan air yang telah dipisahkan dengan etil asetat kemudian di fraksinansi menggunakan butanol sebanyak $500 \mathrm{~mL}$, fraksinasi butanol berupa kecoklatan diperoleh ekstrak kental sebanyak 25,7 dengan rendemen sebesar $0,73 \%$. Hasil fraksinasi yang diperoleh dari ketiga pelarut tersebut kemudian di pekatkan kembali menggunakan rotary vacum evaporator, sehingga menghasilkan ekstrak kental, selanjutnya di uapkan di atas waterbath dengan suhu $50^{\circ} \mathrm{C}$ sampai mengental, selanjutnya ekstrak kental yang diperoleh akan digunakan dalam uji aktivitas antibakteri (Purwanto, 2015).

Metode yang dipilih pada pengujian aktivitas antibakteri fraksi n-heksan, etil asetat dan butanol adalah metode difusi kertas cakram. Dengan konsentrasi 31,25 $\mu \mathrm{g} / \mathrm{mL}, \quad 61,25 \mu \mathrm{g} / \mathrm{mL}, 125 \mu \mathrm{g} / \mathrm{mL}, 250$ $\mu \mathrm{g} / \mathrm{mL}$, dan $500 \mu \mathrm{g} / \mathrm{ml}$ yang diteteskan pada kertas cakram. Sebagai kontrol positif digunakan blandisk yang berisi Chloramphenikol $30 \mu \mathrm{g}$ bakteri yang diguanakan S. aureus dan E.coli. kontrol positif berfungsi sebagai kontrol dari zat uji (fraksi daun areuy kikunti) dengan membandingkan zona hambat yang terbentuk. Kontrol negatif yang digunakan adalah DMSO, kontrol negatif berfungsi untuk mengetahui ada tidaknya pengaruh pelarut terhadap pertumbuhan bakteri $\mathrm{S}$. aureus dan E.coli. sehingga dapat diketahui bahwa yang mempunyai aktivitas antibakteri adalah zat uji bukan pelarut (Sari et al., 2011).

Hasil uji aktivitas antibakteri menunjukkan bahwa fraksi daun areuy 
kikunti dapat menghambat pertumbuhan bakteri S. aureus pada fraksi etil asetat. Hasil pengukuran zona hambat dari fraksi

Hasil Pengujian Aktivitas Antibakteri Fraksi N-Heksan, Fraksi Etil-Asetat Dan Fraksi Butanol Daun Areuy Kikunti (Photos junghuhni de vreise) Terhadap Bakteri Staphylococcus aures ATCC 25923 dan Escherichia Coli ATCC 25922

\begin{tabular}{|c|c|c|c|}
\hline \multirow[b]{2}{*}{ Fraksi Uji } & \multirow[b]{2}{*}{$\begin{array}{c}\text { Konsentrasi } \\
\quad(\mathrm{ug} / \mathrm{mL})\end{array}$} & \multicolumn{2}{|c|}{ Diameter Daya Hambat (mm) } \\
\hline & & $\begin{array}{l}\text { Staphylococcus } \\
\text { aureus }\end{array}$ & Eschericia Coli \\
\hline \multirow{7}{*}{ N-Heksana } & 500 & 8,5 & 8 \\
\hline & 250 & 7,8 & 7,5 \\
\hline & 125 & 7,5 & 7 \\
\hline & 62,5 & 0 & 0 \\
\hline & 31,25 & 0 & 0 \\
\hline & KKP & 25,4 & 20 \\
\hline & KKN & 0 & 0 \\
\hline \multirow{7}{*}{ Etil Asetat } & 500 & 10,5 & 8,5 \\
\hline & 250 & 9,8 & 8 \\
\hline & 125 & 7 & 7,8 \\
\hline & 62,5 & 0 & 0 \\
\hline & 31,25 & 0 & 0 \\
\hline & KKP & 26,5 & 20 \\
\hline & KKN & 0 & 0 \\
\hline \multirow{7}{*}{ Butanol } & 500 & 7,8 & 7,8 \\
\hline & 250 & 0 & 7,5 \\
\hline & 125 & 0 & 0 \\
\hline & 62,5 & 0 & 0 \\
\hline & 31,25 & 0 & 0 \\
\hline & KKP & 20,5 & 20 \\
\hline & $\mathrm{KKN}$ & 0 & 0 \\
\hline
\end{tabular}

Keterangan:

KKP: (Kelompok kontrol Positif): Kloramphenikol disk

KKN: (Kelompok kontrol Negatif): DMSO

Berdasarkan hasil uji aktivitas pada fraksinasi Daun Areuy kikunti yang menujukkan bahwa semakin tinggi konsentrasi, maka diameter zona hambat yang dihasilkan semakin besar, pada kontrol positif pada fraksi Etil asetat memiliki zona hambat yang kuat yaitu 26,5 mm. Konsentrasi pada fraksi yang memiliki zona hambat terbaik yaitu pada konsentrasi $500 \mu \mathrm{g} / \mathrm{mL}$. yaitu $10,5 \mathrm{~mm}$ golongan lemah dan diikuti konsentrasi daun Areuy Kikunti terhadap bakteri dapat dilihat pada tabel 1 .

\section{Tabel 1}


Uji Aktivitas Anti Bakteri dari Fraksi Daun Areuy Kikunti (Pothos Junghuhnii De Vreise) terhadap Bakteri Staphylococcus Aureus dan Escherichia Coli

dalam bakteri Escherichia coli melindungi bakteri dari antibiotik. Inilah mengapa bakteri Staphylococcus aureus lebih rentan dihancurkan oleh bakteri dibandingkan Escherichia coli sehingga pada penelitian ini zona hambat Staphylococcus aureus lebih besar dibandingkan Escherichia coli.

Fraksi n-heksan juga mempunyai aktivitas antibakteri terhadap pertumbuhan bakteri staphylococcus aureus dan Escherichia coli meskipun diameter zona hambat yang dihasilkan lebih besar dari fraksi etil asetat. Fraksi n-heksan daun areuy kikunti efektif dalam menghambat pertumbuhan bakteri Staphylococcus

\begin{tabular}{cc}
\hline Diameter Zona Hambat & Kekuatan aktivitas antibakteri \\
\hline$<5 \mathrm{~mm}$ & Lemah \\
\hline $5-10 \mathrm{~mm}$ & Sedang \\
\hline $10-20 \mathrm{~mm}$ & Kuat \\
\hline$>20 \mathrm{~mm}$ & Sangat kuat \\
\hline
\end{tabular}

Berdasarkan kriteria tersebut, maka daya antibakteri dari hasil uji aktivitas terhadap bakteri Staphylococcus aureus dan Escherichia coli dengan tiga fraksi, diperoleh senyawa bioaktif antibakteri daun areuy kikunti yang ditarik oleh pelarut etil asetat memiliki diameter zona hambat yang paling besar dibandingkan dengan pelarut $\mathrm{n}$-heksan dan butanol. Hal ini menjukkan bahwa fraksi yang paling aktif bila dibandingkan dengan kedua fraksi lainnya terhadap bakteri Staphylococcus aureus dan Escherichia

coli. Penentuan Konsentrasi Hambat Minimum (KHM fraksi etil asetat menggunakan konsentrasi $500 \mu \mathrm{g} / \mathrm{mL}$, $250 \mu \mathrm{g} / \mathrm{mL}, \quad 125 \mu \mathrm{g} / \mathrm{mL}, \quad 62,5 \mu \mathrm{g} / \mathrm{mL}$, $31,25 \mu \mathrm{g} / \mathrm{mL}$ hasil penentuan Konsentrasi Hambat Minimum (KHM) pada masingmasing konsentrasi dapat dilihat pada tabel 2. Penentuan KHM bertujuan untuk mengetahui kekuatan aktivitas antibakteri terkecil yang mampu menghambat pertumbuhan Staphylococcus aureus dan Escherichia coli (Wardhani \& Sulistyani, 2012).

Tabel 2

Diameter Zona Hambar Fraksi Etil asetat terhadap bakteri Staphylococcus aureus dan Escherichia coli

\begin{tabular}{|c|c|c|c|}
\hline \multirow[b]{2}{*}{ Fraksi Uji } & \multirow[b]{2}{*}{$\begin{array}{c}\text { Konsentrasi } \\
(\mu \mathrm{g} / \mathbf{m L})\end{array}$} & \multicolumn{2}{|c|}{ Diameter Daya Hambat (mm) } \\
\hline & & $\begin{array}{c}\text { Staphylococcus } \\
\text { aureus }\end{array}$ & Eschericia Coli \\
\hline \multirow{7}{*}{ Etil asetat } & 500 & 10,5 & 8,5 \\
\hline & 250 & 9,8 & 8 \\
\hline & 125 & 7,8 & 7 \\
\hline & 62,5 & 0 & 0 \\
\hline & 31,25 & 0 & 0 \\
\hline & KKP & 26,5 & 20 \\
\hline & KKN & 0 & 0 \\
\hline
\end{tabular}


Nilai Konsentrasi Hambat Minimum fraksi Etil Asetat terhadap bakteri Staphylococcus aureus dan Escherichia coli konsentrasi $125 \mu \mathrm{g} / \mathrm{mL}$ dengan zona hambat pada bakteri Staphylococcus aureus dan 7,8 dan Escherichia coli 7 termasuk ke dalam aktivitas bakteri yang lemah.

Pada konsentrasi dengan perlakuan yang sama dengan fraksi n-heksan dan butanol di dapatkan diameter pada masingmasing konsentrasi seperti pada tabel 3 .

Tabel 3

Diameter Zona Hambat Fraksi N-heksan terhadap bakteri Staphylococcus aureus dan Escherichia coli

\begin{tabular}{|c|c|c|c|}
\hline \multirow[b]{2}{*}{ Fraksi Uji } & \multirow[b]{2}{*}{$\begin{array}{c}\text { Konsentrasi } \\
(\mu \mathrm{g} / \mathbf{m L})\end{array}$} & \multicolumn{2}{|c|}{ Diameter Daya Hambat (mm) } \\
\hline & & Staphylococcus aureus & Eschericia Coli \\
\hline \multirow{7}{*}{ N-Heksana } & 500 & 8,5 & 8 \\
\hline & 250 & 7,8 & 7,5 \\
\hline & 125 & 7,5 & 7 \\
\hline & 62,5 & 0 & 0 \\
\hline & 31,25 & 0 & 0 \\
\hline & KKP & 25,4 & 20 \\
\hline & KKN & 0 & 0 \\
\hline
\end{tabular}

Nilai Konsentrasi Hambat Minimum fraksi N-heksan terhadap bakteri Staphylococcus aureus dan Escherichia coli konsentrasi $125 \mu \mathrm{g} / \mathrm{mL}$ dengan zona hambat

Tabel 4

\begin{tabular}{|c|c|c|c|}
\hline \multicolumn{4}{|c|}{ Escherichia coli } \\
\hline \multirow[b]{2}{*}{ Fraksi Uji } & \multirow[b]{2}{*}{$\begin{array}{c}\text { Konsentrasi } \\
(\mu \mathrm{g} / \mathrm{mL})\end{array}$} & \multicolumn{2}{|c|}{ Diameter Daya Hambat $(\mathrm{mm})$} \\
\hline & & Staphylococcus aureus & Eschericia Coli \\
\hline \multirow{7}{*}{ Butanol } & 500 & 7,8 & 7,8 \\
\hline & 250 & 7 & 7,5 \\
\hline & 125 & 0 & 0 \\
\hline & 62,5 & 0 & 0 \\
\hline & 31,25 & 0 & 0 \\
\hline & KKP & 20,5 & 20 \\
\hline & KKN & 0 & 0 \\
\hline
\end{tabular}

pada bakteri Staphylococcus aureus dan 7,5 dan Escherichia coli 7 termasuk ke dalam aktivitas bakteri yang lemah.

\section{Diameter Zona Hambar Fraksi Butanol terhadap bakteri Staphylococcus aureus dan Escherichia coli}

\begin{abstract}
Nilai Konsentrasi Hambat Minimum fraksi Butanol terhadap bakteri Staphylococcus aureus dan Escherichia coli konsentrasi $250 \mu \mathrm{g} / \mathrm{mL}$ dengan zona hambat pada bakteri Staphylococcus aureus dan 7 dan Escherichia coli 7,5 termasuk ke dalam aktivitas bakteri yang lemah Konsentrasi fraksi etil asetat, N-heksan dan butanol mempunyai diameter hambat yang berbeda
\end{abstract}

sesuai perbedaan konsentrasinya. Semakin besar konsentrasi semakin besar pula diameter hambat yang dibentuknya.

\section{Kesimpulan}

Berdasarkan penelitian yang sudah dilakukan dapat di simpulkan Fraksi Nheksan, Etil asetat dan Butanol Daun Areuy kikunti (Photos jughuhnii de vreites) memiliki 
aktivitas terhadap bakteri Staphylococcus aureus dan Escherichia coli.

Fraksi yang paling aktif dalam penghambatan pertumbuhan bakteri adalah Fraksi Etil asetat pada konsentrasi $500 \mu \mathrm{g} / \mathrm{mL}$ yaitu 10,5 mm dalam kategori lemah, Bakteri Staphylococcus aureus pada fraksi etil asetat menujukkan aktivitas pada konsentrasi 500 $\mu \mathrm{g} / \mathrm{mL}$ dengan diameter $10,5 \mathrm{~mm}$ dan pada bakteri Escherichia coli menujukkan aktivitas pada konsentrasi $500 \mu \mathrm{g} / \mathrm{mL}$ dengan diameter $8,5 \mathrm{~mm}$.

\section{BIBLIOGRAFI}

Bhandary, M. J., Chandrashekar, K. R., \& Kaveriappa， K. M. (1995). Medical Ethnobotany Of The Siddis Of Uttara Kannada District, Karnataka, India. Journal Of Ethnopharmacology, 47(3), 149-158. Google Scholar

Dewi, P. S., Darmadi, I. G. W., \& Marwati, N. M. (2014). Hubungan Faktor-Faktor Sanitasi Rumah Dengan Kejadian Infeksi Saluran Pernapasan Akut Di Wilayah Kerja Puskesmas Iv Denpasar Selatan Tahun 2014. Jurnal Kesehatan Lingkungan, 4(2), 175-180. Google Scholar

Fitri, L., \& Yasmin, Y. (2011). Isolasi Dan Pengamatan Morfologi Koloni Bakteri Kitinolitik. Jurnal Biologi Edukasi, 3(2), 20-25. Google Scholar

Handoko, R. (2013). Aktivitas Antibakteri Ekstrak Etanol Daun Tumbuhan Sala (Cynometra Ramiflora L.) Terhadap Bakteri Staphylococcus Epidermidis, Pseudomonas Aeruginosa, Dan Klebsiella Pneumoniae Serta Bioautografinya. Universitas Muhammadiyah Surakarta. Google Scholar

Kumoro, A. C. (2015). Teknologi Ekstraksi Senyawa Bahan Aktif Dari Tanaman Obat. Yogyakarta: Plantaxia. Google Scholar
Marliana, E., \& Saleh, C. (2011). Uji Fitokimia Dan Aktivitas Antibakteri Ekstrak Kasar Etanol. Fraksi NHeksana, Etil Asetat Dan Metanol Dari Buah Labu Air. Google Scholar

Nagappan, T., Ramasamy, P., Wahid, M. E. A., Segaran, T. C., \& Vairappan, C. S. (2011). Biological Activity Of Carbazole Alkaloids And Essential Oil Of Murraya Koenigii Against Antibiotic Resistant Microbes And Cancer Cell Lines. Molecules, 16(11), 9651-9664. Google Scholar

Pertanian, K. (2012). Pengembangan Kawasan Rumah Pangan Lestari (Krpl). Kementerian Pertanian. Jakarta. Google Scholar

Purwanto, S. (2015). Uji Aktivitas Antibakteri Fraksi Aktif Ekstrak Daun Senggani (Melastoma Malabathricum L.) Terhadap Escherichia Coli. Jurnal Keperawatan Sriwijaya, 2(2), 84-92. Google Scholar

Raihana, R., Faridah, Q. Z., Julia, A. A., Abdelmageed, A. H. A., \& Kadir, M. A. (2011). In Vitro Culture Of Curcuma Mangga From Rhizome Bud. Journal of Medicinal Plants Research, 5(28), 6418-6422. Google Scholar

Restiana, N. (2019). Materi Kompetensi Matematika Lulusan Smk Dan Kebutuhan Dunia Industri. Gauss: Jurnal Pendidikan Matematika, 2(1), 45-55. Google Scholar

Sari, P. P., Rita, W. S., \& Puspawati, N. M. (2011). Identifikasi Dan Uji Aktivitas Senyawa Tanin Dari Ekstrak Daun Trembesi (Samanea Saman (Jacq.) Merr) Sebagai Antibakteri Escherichia Coli (E. Coli). Jurnal Kimia (Journal Of Chemistry). Google Scholar

Wardhani, L. K., \& Sulistyani, N. (2012). Uji Aktivitas Antibakteri Ekstrak Etil Asetat Daun Binahong (Anredera Scandens (L.) Moq.) Terhadap Shigella Flexneri 
Purwati, Wahyuli

Beserta Profil Kromatografi Lapis Tipis.

Jurnal Ilmiah Kefarmasian, 2(1), 1-6.

Google Scholar

\section{Copyright holder:}

Purwati, Wahyuli (2022)

\section{First publication right: \\ Jurnal Health Sains}

This article is licensed under:

(c) 